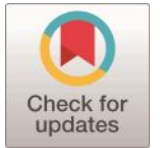

Article Type: Research Paper

\title{
Determinants of Mudharabah Term Deposit: A Case of Indonesia Islamic Banks
}

\author{
Fachru Nurul Umam ${ }^{1 *}$, Annisa Nur Salam², and Achmad Rizal ${ }^{3}$
}

AFFILIATION:
${ }^{1}$ Master of Science in Islamic
Finance, INCEIF The Global
University of Islamic Finance,
Malaysia
2 Faculty of Islamic Economics and
Business, UIN Sunan Gunung Djati,
West Java, Indonesia
3 Sharia Economics, Faculty of
Islamic Economics and Business,
UIN Sunan Kalijaga, Special Region
of Yogyakarta, Indonesia

*CORRESPONDENCE:

fachrunurulumam@gmail.com

THIS ARTICLE IS AVAILABLE IN:

http://journal.umy.ac.id/index.php/jerss

DOI: $10.18196 /$ jerss.v5i2.12445

\section{CITATION:}

Umam, F.N., Salam, A.N., \& Rizal, A. (2021). Determinants of Mudharabah Term Deposit: A Case of Indonesia Islamic Banks. Journal of Economics Research and Social Sciences, 5(2), 167-180.

\begin{abstract}
The growth of Islamic finance industries in Indonesia has shown significant improvement. The increased number of surplus units depositing their funds in Islamic banks has become a significant factor in their trust and confidence in Islamic banking products. One of the products utilized by the depositor is the mudharabah deposit product, where the Islamic bank offers higher profit compared to other types of deposit or saving. This paper aims to analyze the issues in a mudharabah term deposit in the Islamic banking industry in Indonesian Islamic banks. The issues concern more on the profit and risk in the mudharabah concept that has been applied in Islamic banks and the variables that affect the changes in mudharabah deposit product. We used the sample to analyze the issues by selecting 14 Islamic banks in Indonesia from 2011-2020. This research uses a quantitative approach with multiple linear regression analysis methods. Several variables are considered the independent variables to know the changes in the demand of mudharabah deposits in the Islamic bank, including interest rate, profit rate, number of office or branch units, and nonperforming financing. Our analysis shows that the number of offices or branch units and non-performing financing positively impact the changes in demand of mudharabah deposits, while the interest rate and profit rate have a negative impact on mudharabah deposits.

Keywords: Deposit; Islamic Bank; Mudharabah; Ordinary Least Square JEL Classification: G21, C2
\end{abstract}

\section{Introduction}

The Islamic banking industry in Indonesia has experienced significant growth. In recent 2021, there was surprising news in the Indonesian Islamic banking industry, when the three larger Islamic banks were merged on the first of February 2021, it gives the strong signal that the government has put their effort and plan to increase the performance of the business as well as the growth of Islamic banking industry in Indonesia. The merger of the larger Islamic bank positively impacts the country as well. It has been proved that the Islamic finance industry's growth has increased more than $22 \%$ in 2020 , which is almost double compared to the growth in 2019. The significant development of Islamic finance can be a factor in Indonesian awareness and confidence being highly contributed as an essential element to move to Islamic banking products. It has become an alternative decision as an effective financing tool in majority Muslim countries and non-Muslim countries, such as the UK, South Africa, Hongkong, and Luxembourg (Alawode \& Iqbal, 2015). 
Due to the country's plan to strengthen the development of the Islamic finance industry, the Head executive of Otoritas Jasa Keuangan had launched the road map of Indonesia Islamic Banking 2020-2025 with three main objectives and eleven policies direction to ensure the growth and stability of Islamic finance industry in Indonesia are being promoted. The Indonesian economic growth has experienced a contraction in the fourth quarter of 2020, with negative growth of 5,3\% due to the Covid-19 pandemic (BPS, 2020). However, Islamic banking industries can survive and run their business to ensure that customers still have access to Islamic banking products. As a result, the growth of total assets of Islamic commercial banks has experienced positive growth from year to year. According to Islamic Banking Statistic (Dec, 2020), the number of deposit funds in Islamic banks is dominated by mudharabah deposits which contributed up to $50 \%$ to the total Islamic banking fund, while the remaining was in the forms of wadiah demand deposit, wadiah saving and mudharabah saving. Thus, the mudharabah deposit was one of the significant contributions to the funds raised by Islamic banks. It will help the Islamic banking industry grow and give more access to financing to generate more returns from financing.

Table 1 The Growth of Islamic Banks in Indonesia

\begin{tabular}{ccccc}
\hline Indicators & $\begin{array}{c}\text { Islamic Banks } \\
\text { (Unit) }\end{array}$ & $\begin{array}{c}\text { Total Number of } \\
\text { Offices (unit) }\end{array}$ & $\begin{array}{c}\text { Total Assets (in } \\
\text { billion IDR) }\end{array}$ & $\begin{array}{c}\text { Islamic Business } \\
\text { Units (Unit) }\end{array}$ \\
\hline 2011 & 11 & 2,101 & 148,987 & 24 \\
2012 & 11 & 2,380 & 149,321 & 24 \\
2013 & 11 & 2,526 & 306,230 & 23 \\
2014 & 12 & 2,483 & 272,343 & 23 \\
2015 & 12 & 2,301 & 296,262 & 22 \\
2016 & 13 & 2,201 & 356.504 & 21 \\
2017 & 13 & 2,169 & 424.181 & 20 \\
2018 & 14 & 2,229 & 477.327 & 20 \\
2019 & 14 & 2,300 & 524.564 & 20 \\
\hline 2020 & 14 & 2,426 & 593,948 & \\
\hline
\end{tabular}

Source: OJK (2020)

Based on the Table 1 data, the total asset of Islamic commercial banks has experienced significant growth. The total asset in 2020 has increased roughly 13\% compared to 2019 . While the increase in the number of Islamic banks also positively impacts the Islamic banking industry, the significant growth in total assets can be a factor of the significant increase in total deposits as banking liability. The more the depositor puts their money in the Islamic banks, the more they provide their customers. It is also supported by the increase in the number of offices or branches of Islamic banks where it can facilitate the customer to put their money in Islamic banks. Therefore, the increase in the number of banks will positively impact the growth of the Islamic banking industries in Indonesia. The data above also explained that the growth of Islamic banking industries in Indonesia has a positive signal in the future. In the last seven years of banking, industries have been operating in Indonesia. As a result, there is a gradual increase in terms of their asset. This positive signal will bring Islamic banks more confidence, supporting the development of Islamic banking industries in Indonesia. 
The deposit product in Islamic banks in Indonesia has been differentiated into three categories: demand, saving, and investment deposit (Che Arshad \& Nurfadilah, 2017). In addition, the mudharabah deposit is also one of the significant products that contributed to the deposit funds.

Table 2 The growth of Mudharabah Deposit in Islamic Banks in Indonesia

\begin{tabular}{ccc}
\hline Year & $\begin{array}{c}\text { Mudharabah Deposit } \\
\text { (in Billion IDR) }\end{array}$ & $\begin{array}{c}\text { Growth } \\
(\%)\end{array}$ \\
\hline 2011 & 70,806 & $19.67 \%$ \\
2012 & 84,732 & $27.24 \%$ \\
2013 & 107,812 & $25.8 \%$ \\
2014 & 135,629 & $3.39 \%$ \\
2015 & 140,288 & $18.5 \%$ \\
2016 & 166,174 & $18.08 \%$ \\
2017 & 196,226 & $8.95 \%$ \\
2018 & 213,794 & $5.54 \%$ \\
2019 & 225,646 & $5.58 \%$ \\
\hline 2020 & 238,888 & \\
\hline
\end{tabular}

Source: OJK (2020)

Based on Table 2, the amount of mudharabah deposits has substantial growth from year to year, especially in 2014, where the growth rate of mudharabah deposits has increased dramatically. However, in the recent year of 2019 and 2020, there is no significant growth in terms of mudharabah deposits. The slow growth could be affected by the spread of pandemic covid-19 throughout the year as it only increased around $5.58 \%$ in 2020. The significant growth also happened in 2017, where the increase of the mudharabah deposit has reached $18 \%$. The continuous growth in mudharabah deposits will benefit Islamic banks to allocate the fund to finance the bank business as the source of funds from Islamic banks comes from deposits made by surplus units.

Mudharabah deposits on the Islamic bank are affected by many variables. The changes in the profit rate do not solely determine it, but other factors could be elements that can affect the changes in the mudharabah deposit. In the case of 2020, the changes on the mudharabah deposit are unique, which in the first month of January, mudharabah deposit product started to decrease. However, as it is reaching the end of 2020, the mudharabah deposit continues to increase. The main reason for this notable change is the covid-19 situation where the depositors are afraid to deposit their funds based on the profit and loss sharing concept. As the Covid-19 pandemic brings uncertainty to the market, they will choose safer saving instruments other than mudharabah deposit products so that the depositors are not exposed to a broader range of risks. The concept of mudharabah deposit, according to Pratiwi (2020), are an investment fund placed by the depositors which are not contradicting the shariah for a certain period, and withdrawal can be made at a particular time based on a contractual agreement between the depositor and the bank typically 1,3,6 and 12 months.

Various factors influence Mudharabah deposits. Based on research by Che Arshad and Nurfadilah (2017) and Syamsulhakim (2004), changes in mudharabah deposits are 
affected by the changes in the profit rate of mudharabah contract. The study made by Anuar, Mohamad and Shah (2014) confirms that the interest rate affects the profit rate of Islamic banks whether in the short run and long run. The transparency of risk associated with mudharabah deposits should also be considered so that the available information on risk mitigation could help depositors manage their risk in this Islamic baking product satisfied (Archer \& Karim, 2009). Therefore, this study aims to analyze the effect of interest rates, profit rates, number of bank offices and non-performing financing variables on the mudharabah deposit variable.

The intercorrelation between risk and profit is the main feature differentiating between the Islamic and modern economies. It is deemed as a just and fair concept of the Islamic system. Agha and Sabirzyanov (2015) said that the profit could be justified when it undertakes a proportionate risk and should not be created from the risk-free contract. Ibn Taymiyyah said, "Risk falls into two categories, commercial risk, where one would buy a commodity in order to sell it for profit and rely on Allah for that. This risk is necessary for merchants, and although one might occasionally lose, this is the nature of commerce. The other type of risk is that of gambling, which implies eating wealth for nothing (اكل المال بالباطل). It is what Allah and His Messenger (P.B.U.H.) prohibited" (as cited in Agha and Sabirzyanov, 2015). The risk in business is necessary when it is associated with the reward or profit. As it is explained by one of the maxims which justifies the essential risk associated with the return based on Islamic economic transaction, 'الغنم بالغرم,' "Entitlement to profit is accompanied by responsibility for attendant expenses and possible loss" (Tyser, Demetriades, \& Effendi, 2000). Thus, the element of risk involved would justify the validity of Islamic transactions, as the transaction without participating in any risk would not be acceptable (Al Maddah, 2017). Seho, Alaabed, and Masih (2016) stated that risk-sharing financing in Islamic banks, for example, should be promoted as it facilitates the resilience and development of the Islamic banking and finance industry extensively. Rosly and Zaini (2008) stated that uncertainty about the future even could also be positive. Meaning that taking a risk can lead to making a profit as well as losses. To that extent, the importance of managing risk associated with the return is encouraged in Islam. On the other hand, Islam does not encourage the risk-free rate on the interest on the loan. The concept of risk in Islam is divided into many instruments. As applied in the loan or debt instrument, risk transfer is not encouraged in Islam because no justice is promoted between the parties.

Mudharabah is widely known as a profit-loss sharing contract. In recent years it was popular with the concept of risk-sharing, which means that the capital provider and entrepreneur have to share their risk in the case of losses, where the rabbul maal will incur a loss in terms of capital that they provided, and on the other hand the entrepreneur will suffer a loss due to effort in performing the business. Both have their own risk associated with the profit-sharing agreement. When it comes to the profit generated from mudharabah, the return will be distributed according to the pre-preagreed profit ratio that both parties have agreed. In Islamic banks, the mudharabah term deposit has been widely used to cooperate between the owner of capital who does not have any expertise and the entrepreneur who has the skill to do the business (Hassan \& Bello, 2014). Islamic banks will act as an entrepreneur while the depositor is 
the capital provider given to the bank in which the banks will utilize it to provide financing to their customer to generate a return.

The advantage of using the mudharaba term deposit is that the Islamic bank's profit rate is usually higher than the savings account based on the wadiah contract. However, there are still some issues regarding the concept that has been applied in mudharabah deposits for Islamic banking. The structure of mudharabah deposits in Islamic banks is placed under bank liability, in which the bank is liable for the fund that has been utilized. In the case that the bank has incurred loss due to customer default when providing financing used by the mudharabah deposit. Under banking regulation, the deposited money will be guaranteed by the bank. Hassan and Bello (2014) stated that general guarantees on all investment deposits seem susceptible to riba, where the capital should not be guaranteed under classical mudharabah.

Rosly and Zaini (2008) stated that it is a risky product for Islamic banks if the underlying contract is based on a profit and loss sharing system, profit will be distributed when the investment is generating a return, while the depreciation in the capital may occur when there is a loss incurred in the investment. Thus, the Islamic bank is at high risk as customers' money is under the bank's guarantee. Therefore, Iwona (2019), the principle of profit and loss sharing applied in terms of investment, the probability that depositor will lose their capital is exposed under the mudharabah contract.

One of the issues arises in mudharabah deposit is the safety of deposit for depositor under mudharabah mechanism. The organized mudharabah on the Islamic banks is called parallel mudharabah. A third party involved in the mudharabah, depositor as a rabbul maal, would deposit their money in the bank using a mudharabah contract. Then bank act an entrepreneur will then utilize the deposit money for investment purposes. As a result of parallel mudharabah, Islamic banks will choose the third party who needs funds, expertise, or skill to run. In the end, the profit will be shared between the entrepreneur and rabbul mall. It is how the general concept of parallel mudharabah has been applied in Islamic banking industries. The principle of result in mudharabah or musharakah is different from the principle of fixed interest rate in which the bank will provide a fixed return to their customer regardless of the result of the project generated, whether it is making profit or losses.

Suppose we look at the classical concept of the mudharabah contract. The capital under mudharabah is not guaranteed. Because the entrepreneur acts as an agent to operate the business with their skill and effort, it is not considered a liability under the entrepreneur, and he is not liable to guarantee the capital unless it is due to misconduct or negligence in the hand of an entrepreneur. However, in Islamic banks in Indonesia, the capital is guaranteed by a third party called Lembaga Penjamin Simpanan (LPS). Rahman (2015) stated that guaranteeing deposits of Islamic banks is a need for depositors who are depositing their money in the bank, and it is based on the principle of justice and adl, only in terms of return which is not guaranteed. 
However, the classical mudharabah has described the context of justice and fairness in the mudharabah concept, where both parties have their own risk associated with the contract. In Malaysia and Indonesia, the capital under mudharabah deposit is guaranteed by the third party, which are third party guarantee. The Islamic deposit insurance in Malaysia, for example, is introduced and authorized by the Shariah Advisory Council of Bank Negara Malaysia under the principle of kafalah bil ujrah or guarantee with fee (Rahman, 2015). It is allowed as long as the guarantee is under mudharib and it should be a free voluntarily act, which is not binding and based on tabarru. Moreover, the guarantee may be only in terms of capital did not include the profit itself because if the profit is guaranteed under mudharabah deposit, it will be considered riba, which is prohibited in Islam.

In the classical concept of Islamic transaction, Allah has stated the permissibility of trade and mentioned in the Quran Surah Al-Baqarah verse 275 "That is because it has been said: Trade is like riba. However, Allah has permitted trade and prohibited riba. After receiving directions from their Lord, those who desist shall be pardoned, and for the past, their case is for Allah to judge. Nevertheless, those who repeat (the offense) are companions of the fire. They will abide therein forever." From this verse, it is mentioned that Allah has prohibited riba-based transactions and has allowed trade as the main business for Islamic activity. The concept of profit and risks in the trade or al bay has been implemented in the concept of mudharabah. Where in the concept of mudharabah, both parties are concerned about the risk associated with the business. It has a similarity where the business carries high risks; the return or profit should also be high. It complies with the qawaid fiqhiyyah that stated no profit without taking any risk. The risk associated in mudharabah contract to mudharabah depositors is the capital depreciation or even diminishing on their capital provided for the investment, meaning that if the capital provider is entailed to the risk in terms of capital contribution, the return on the investment should be justified by the risk associated in the investment. It makes the differences between the classical concept of musharakah and mudharabah, wherein musharakah, the loss of capital contribution, will be borne by both parties. In contrast, in mudharabah, the capital loss will be borne by one party, whereas the other party as an entrepreneur will experience losses in terms of the effort and time contributed to the business.

The concept of risk in Islamic banking is undoubtedly different from conventional banking, in the principle of Islamic banking transaction, where the underlying concept is taken from the sales transaction provided that there should be the ownership of assets in the hand of the banks. Therefore, the risk associated with this transaction is much higher than conventional banks, which only refer to the loan or debt principles. Therefore, no such risk is involved because the conventional bank does not hold any asset exposed to inventory, price, and own risk. However, Islamic banks will suffer greater risk than conventional ones because the nature and principle of Islamic banks are based on the sales and profit loss sharing concept (Sundararajan and Errico, 2002; Venardos, 2005). 
According to Rosly and Zaini (2008), profit and loss sharing are entailed as the mudharabah depositor and the Islamic bank capital provider-entrepreneurship relationship in terms of profit and loss sharing agreement. The nature of the mudharabah contract will determine the Islamic bank's performance in utilizing the deposited fund by the customer, which has a relationship to the profit distribution to the mudharabah depositor. The more profit-sharing the bank provides as a return from investment, the more attractive the mudharabah product is to the depositor.

The study conducted by Sutrisno (2020) stated that profit-sharing did not affect mudharabah deposits in Islamic banks in Indonesia. It means that other factors could affect the demand for mudharabah deposits. However, Che Arshad and Nurfadilah (2017) found that the changes in mudharabah deposits are affected by the changes in the profit rate of the mudharabah contract. It is in line with the study conducted by Rachmawati and Syamsulhakim (2004) that with every increase of $1 \%$ of profit sharing, the demand for mudharabah deposit will increase by IDR 39,917.48 Million. This finding concluded that the demand for mudharabah deposits is not only determined by the religious aspect. It also shows that the profit motive could be why the demand for mudharabah deposits increases. Interest rate is considered as a primary tool for the conventional bank to generate profit.

On the other hand, it is also one of the determinants behaviors for depositors to save their money in the conventional bank (Che Arshad \& Nurfadilah, 2017). As the main distinction between Islamic banks and conventional banks is in terms of the interest rate offered. In Islamic banks, the return generated from financing is basically from non-ribabased transactions that consider profit rate as a benchmark for them to generate a return. The implementation of profit rate in Islamic banks is based on the Quran and hadith where trades come. The distinctive element that makes the Islamic banking industry resilient in a crisis is that they contribute to the actual sale transaction compared to conventional banks that only offer loans where no such actual transaction occurred. However, the study made by Anuar et al. (2014) confirms that the interest rate affects the profit rate of Islamic banks whether in the short run and long run. Moreover, the changes in interest rate could have a significant effect on the profit rate but not on the contrary.

However, the effect on interest rate is less altered in Islamic financial companies compared to conventional banks. The main idea on the effect of interest rate is that the Islamic deposit rate should be different from the conventional one due to the differences in the principle of the product. The conventional banks use the concept of interest on deposit, while the Islamic product would be based on a hibah or profitsharing agreement. Thus, make the Islamic banks different from the conventional in theory. However, when it comes to practice, the effect on interest rate is basically and strong changes on the profit rate, this is because the dual banking system could be one factor that affects the changes on the interest rate to affect the movement on the profit rate. The Islamic banks run parallel with the conventional banks on the dual banking system (Anuar et al., 2014). Because the Islamic banks are operating under a dual 
banking system, there would be an exposure toward the cross deposit on the dual banking system (Ismath Bacha, 2008).

The concept of mudharabah deposit applied in Islamic banks has raised some issues in terms of shariah-compliant products, and It is because the classical concept of mudharabah is not in line with the organized concept mudharabah in the context of Islamic banks. Such as the relationship between mudharabah deposits to the changes in interest rate, profit rate, and the changes in the bank size could affect the demand for mudharabah deposits. Looking at the other factor that could lead to the attractiveness of the mudharabah deposit, retracted due to the profit-sharing ratio, which is expected, higher than others. However, the issue may arise if the depositor only knows the profitsharing element, but the actual concept of mudharabah is not limited to that point. The transparency of risk associated with mudharabah deposits should also be considered so that the available information on risk mitigation could help depositors manage their risk in this Islamic baking product.

Lack of transparency on the mudharabah account holder will be considered an important issue that could arise. Also, a lack of information regarding the risk associated with the mudharabah contract could lead to less demand for the mudharabah deposit as an attractive instrument to attract customers. The lack of transparency would make it the account holder challenging to manage their account and move to another account if the performance is not satisfied (Archer \& Karim, 2009). It is also one of the problems in the implementation of using smoothing technique whether to stabilize the profit over the financial period or to cover the risk on mudharabah capital can lead to contradicting with the concept of profit and loss principle in mudharabah where the account holder should entitle to some portion of risk involved in mudharabah in the case of loss from the venture. It is in line with the principle of mudharabah as a justice element in shariah. According to Iwona (2019), in some countries such as Malaysia, based on policy guidelines issued by Bank Negara Malaysia stated that smoothing practice is not allowed to be practiced in Islamic banks. It means that neither the capital provider nor the account holder will guarantee capital or fix deposit return mudharabah from their investment. They also entitle to some risk on the capital depreciation along with the performance of the venture itself.

The contribution of this research is the novelty of the data used. In addition, this study combines several independent variables obtained from previous references. Therefore, it is hoped that this research can complement the literature on Islamic finance, especially on mudharabah deposit instruments in Indonesia.

\section{Research Method}

The research was conducted using a quantitative approach. The data used is secondary data obtained from the Financial Services Authority (OJK). The data type used is timeseries data of Islamic banks in Indonesia for the last ten years. The time used in this study is 120 periods from January 2011 to December 2020. The analytical method used 
is multiple regression analysis at a significance level of 0.05 . The independent variables in this study consisted of four independent variables: interest rates, profit rates, number of bank offices, and non-performing financing. At the same time, the dependent variable in this study is the mudharabah deposit. The equation models in this study are:

$$
M D=\alpha+\beta_{1} N O+\beta_{2} E R+\beta_{3} N P F+\beta_{4} D I R
$$

Where $M D$ is mudharabah deposit, is $\alpha$ is constant, $\beta$ is coefficient, $N O$ is the number of bank offices, $E R$ is equivalent rates, $N P F$ is non-performing financing, and $D I R$ is deposit interest rates.

The linear regression analysis model uses the ordinary least squares method (OLS) to see the effect of the independent variable on the dependent variable. The steps used in analyzing the model in this study are the classical assumption test (autocorrelation, heteroscedasticity, multicollinearity and normality test), the coefficient of determination (R-Square) test, the $\mathrm{F}$ difference test and the $\mathrm{T}$ difference test. The classical assumption test is used to ensure that the model used is not biased. The coefficient of determination test is used to see the effect of the independent variable variation on the dependent variable variation. The $F$ test serves to see the effect of the independent variable on the dependent variable simultaneously. At the same time, the T-test serves to partially see the independent variable's effect on the dependent variable.

The time-series data in this study have passed the classic assumption test of autocorrelation, heteroscedasticity, multicollinearity, and normality tests. For this reason, the data can be used for multiple linear regression analysis.

\section{Result and Discussion}

Based on the methodology used, this section explains and discusses the effect of the number of offices, equivalent rate, Non-Performing Financing and deposit interest rate on mudrabah deposit. The description of the data used in this study can be seen in Table 3. The sample or amount of data used in each variable is 120 observations with the mean and standard deviation, more detailed in Table 3.

Table 3 Descriptive Data

\begin{tabular}{lccc}
\hline \multicolumn{1}{c}{ Variables } & Mean & Std. Deviation & N \\
\hline Mudharabah deposit & 145571.1000 & 57669.04023 & 120 \\
Number of offices & 1842.0417 & 232.33858 & 120 \\
Equivalent rate & 6.0259 & 1.02582 & 120 \\
Non-Performing Financing & 5155.9583 & 2623.52388 & 120 \\
Deposit interest rate & 6.5283 & .97629 & 120 \\
\hline
\end{tabular}

Time series data was used to know the effect of an independent variable on its dependent variable. Multiple linear regression is used to perform this analysis. The 
result of the regression shows that selected variables have statistically significant, which predict mudharabah deposit.

Table 4 Multiple Regression Analysis Result

\begin{tabular}{lccc}
\hline Variables & Beta & $\mathrm{t}$ & Sig. \\
\hline (Constant) & & 1476 & .143 \\
Number of offices & .547 & 6.861 & .000 \\
Equivalent rate & -.233 & -2.592 & .011 \\
Non-Performing Financing & .223 & 3.188 & .002 \\
Deposit interest rate & -.267 & -2.627 & .010 \\
\hline
\end{tabular}

Note. Dependent variable: Mudharabah Deposit

Based on the result of the analysis that has been made, it explained that the number of offices or branches, equivalent rate, non-performing financing, and the interest rate have a significant impact on the mudharabah deposit with different significant levels.

The number of offices or branches for Islamic banks is significant to know the inclusivity of the bank to reach and spread the development and growth in an Islamic bank. As the number of branches of Islamic banks increases, the probability of a customer depositing their fund also will increase. It has been explained that the number of offices has contributed significantly to the changes in demand for mudharabah deposits. As the correlation is positive, the increase in the number of offices or branches in Islamic banking in Indonesia would increase the effect on mudharabah deposits. The increased number of offices will ease the mobilization of funds so that the customer can quickly deposit their funds in Islamic banking deposits (Sutrisno, 2020). Jaber and Manasrah (2019) and Madebo (2004) explained that branches of Islamic banks have an important position in collecting funds from their customers. As a result, the increase in the demand for mudharabah deposits is significantly affected by the number of branches or offices of Islamic banks in Indonesia.

An equivalent rate is indicative of return from placement of funds or source of fund (OJK, 2020). If we look at the expected behavior of depositors, they will make a mudharabah deposit in Islamic banks either because Islamic banks offer higher profit than conventional or because of religious belief. This reason mainly affects the demand for mudharabah deposits in Islamic banks. However, the study showed that the profitsharing ratio in the mudharabah deposit negatively affects the deposit. However, the significant impact is not quite substantial compared to other variables that significantly affect the mudharabah deposit. As the result of this study has contradicted the principal concept of human behavior towards profit, people will tend to invest or deposit if the rate of return is favorable. However, if we look at last year's annual report of the overall Islamic bank in Indonesia, it showed that even the profit rate was decreasing throughout the year, but the demand for mudharabah deposits was increasing in that particular year. It could be the impact of the covid-19 pandemic, where people will tend to save their money rather than use it for consumption. As a result, the changes in demand for mudharabah deposit is not mainly due to changes in profit share ratio, and other factors could be the reason what affects the demands of mudharabah deposit. 
Non-performing financing is the ratio of financing to the customer, which is doubtful or lost over the total financing amount (OJK, 2020). NPF has a significant impact on the depositor in Islamic banks, and as the ratio of NPF increases, the consumer will run and take away their fund from Islamic banks due to the high probability of failure in their business (Pradana \& Sampurno, 2013). Because the main objective of the business model of Islamic banks is to provide financing to the deficit units, failure to collect installments from their customer could increase their probability of bankruptcy. The study stated that the decrease in NPF in Islamic banks leads to an increase in mudharabah deposit products; this shows that the NPF and Mudharabah deposit have a positive correlation between them. However, the study that has been conducted by Permataningayu and Mahdaria (2019) stated that non-performing financing does not have a significant impact on the third party funds, meaning that even there is an increase or decrease in the ratio of non-performing financing, the mudharabah deposit will not be affected by that changes on NPF.

Interest rates have a significant impact on the mudharabah deposit, customer in Islamic banks will not be affected by the interest rate if the motive of investment is because of religious belief. Meaning that even the interest rate increases, they will stay at the Islamic banks to use their product compared to conventional banks. Due to the nature of Islamic banks, it is based on interest rate-free transactions where Muslims are not encouraged to deposit and save their funds in the conventional bank based on riba transactions. However, the finding of this study showed a relationship between interest rate and the demand for mudharabah deposits. As the interest rate increase, the demand for mudarabah deposits will then decrease. Therefore, it can be concluded that the main objective of the depositor who is depositing their money in Islamic banks are exposed to interest rate changes. Due to the nature of the mudharabah depositor, it is not solely affected by the profit rate but also the changes in interest rate. This finding explained that the motive of the depositor in the mudharabah deposit is not because of religious belief that aims to run from riba but because of the profit motive to gain the monetary benefit. It is in line with the finding made by Kasri and Kassim (2009) stated that the depositor in Islamic banking industries in Indonesia is rational, means that they will deposit their money in Islamic banks if the interest rate offered in conventional are low and move to conventional if they offer higher interest rate.

\section{Conclusion}

Based on the discussion above, the paper has explained the issue in mudharabah deposits and the factors that affect the changes in demand for mudharabah deposits. Therefore, it can be concluded that some variables are affecting the mudharabah deposit product, such as the number of offices, equivalent rate or profit-sharing ratio, non-performing financing, and deposit interest rate. Furthermore, it showed that the number of offices has and non-performing financing has a positive relationship to the mudharabah deposit product, while the equivalent rate and deposit interest rate have negatively affected the mudharabah deposit demand. Therefore, it means that the changes in mudharabah deposits have a negative relationship with interest rates. As a 
result, the reason why depositors put their money in the Islamic bank based on mudharabah deposit is not mainly on the religious motive, and it is also because of profit motive from depositors, where the depositors are still considering the margin on their deposit product rather regardless Islamic or conventional banks.

Mudharabah deposit products still come with the problematic issues in which the main factor of depositing their money in the bank is not solely due to profit and loss sharing. Also, some are affected due to the changes in interest rate deposit, where the main objective of the depositor who deposits their fund in Islamic banks is based on the profit motive in specific elements and the religious belief that makes depositor in conventional to move to Islamic banks product.

The limitation of this study is that the author still did not elaborate further on how the risk associated with the mudharabah contract can be analyzed. It is difficult for an Islamic bank to analyze the probability of loss due to the risk involved in the product because the future condition is uncertain. This issue could be used for further research where the lack of risk information in mudharabah deposit product to their customer could lead to unattractive mudharabah contract in order for them to mitigate the risk associated with mudharabah deposit product because the main principle of the mudharabah is based on the profit and loss sharing agreement. Hence, the costumes are not entitled only to the information of profit rate in terms of how many percentages the depositors will earn profit based on the mudharabah deposit. However, it is also essential for the bank to have such information on the risks associated with the mudharabah deposit product where the depositors can also have an idea of how to manage the risk and make financial planning in the future.

\section{Acknowledgment}

Acknowledgments are given to the Financial Services Authority (OJK) to support this research with complete data availability.

\section{References}

Agha, S. E. U., \& Sabirzyanov, R. (2015). Risk management in Islamic finance: An analysis from objectives of Shari'ah perspective. International Journal of Business, Economics and Law, 7(3), 46-52. Retrieved from https://www.ijbel.com/wpcontent/uploads/2015/09/RISK-MANAGEMENT-IN-ISLAMIC-FINANCE-ANANALYSIS-FROM-OBJECTIVES-OF-SHARI $\%$ E2\%80\%99AHPERSPECTIVE.pdf

Alawode, A.A., \& Iqbal, Z. (2015). Islamic finance. Retrieved from http://www.worldbank.org/en/topic/financialsector/brief/islamic-finance

Anuar, K., Mohamad, S., \& Shah, M. E. (2014). Are deposit and investment accounts in Islamic banks in Malaysia interest-free?. JKAU: Islamic Econ, 27(2), 29-58. https://doi.org/10.4197/islec.27-2.2 
Archer, S., \& Karim, R. A. A. (2009). Profit-sharing investment accounts in Islamic banks: Regulatory problems and possible solutions. Journal of Banking Regulation, 10(4), 300306. https://doi.org/10.1057/jbr.2009.9

Che Arshad, D. N., \& Nurfadilah, D. (2017). The factors influencing the changes of deposit in Islamic bank: Comparative study between Malaysia and Indonesia. Journal of Islamic Banking and Finance, 5(2), 37-46. https://doi.org/10.15640/jibf.v5n2a6

Financial Services Authority (OJK). (2020). Islamic banking statistics. Retrieved from https://www.ojk.go.id/id/kanal/syariah/data-dan-statistik/statistik-perbankansyariah/default.aspx

Hassan, R., \& Bello, S. A. A. (2014). The concept of mudharabah investment deposits. International Journal of Business Management \& Research (IJBMR), 4(2), 63-74. Retrieved from http://www.tiprc.org/publishpapers/--1394190992THE $\% 20$ CONCEPT $\% 200 F \% 20$ MUDARABAH $\% 20$-.full.pdf

Ismath Bacha, O. (2008). The Islamic inter bank money market and a dual banking system: the Malaysian experience. International Journal of Islamic and Middle Eastern Finance and Management, 1(3), 210-226. https://doi.org/10.1108/17538390810901140

Iwona, S. (2017). Mudaraba term deposits in Islamic banking - the crucial aspects. FINANSE Crasopismo Komitetu Nauk o Finansach PAN, 1(10), 373-382. Retrieved from http://cejsh.icm.edu.pl/cejsh/element/bwmeta1.element.mhp-6edc0ff8-d74f-4b06$\underline{8 \mathrm{e} 3 \mathrm{~b}-33 \mathrm{~d} 54700 \mathrm{c} 2 \mathrm{f} 6}$

Jaber, A. S., \& Manasrah, M. S. (2017). The factors that affect to attract deposits in Palestinian Islamic banks. Asian Journal of Finance \& Accounting, 9(1), 261-274. https://doi.org/10.5296/ajfa.v9i1.11020

Madebo, S.A. (2004). Factors affecting deposit mobilisation in private commercial banks: The case of Awash International Bank S.C. Thesis Master. St. Mary's University College.

Permataningayu, G., \& Mahdaria, S. (2019). The effect of non-performing financing and financing to deposit ratio on Islamic banks financing in Indonesia. Asian Journal of Islamic Management (AJIM), 1(1), 28-37. https://doi.org/10.20885/ajim.vol1.iss1.art3

Pradana, Y., \& Sampurno, R. D. (2013). Analisis pengaruh LDR, CAR, ROA, dan faktor eksternal perbankan terhadap volume KPR pada bank persero periode 2008-2012. Diponegoro Journal of Management, 2(3), 338-352. Retrieved from https:// ejournal3.undip.ac.id/index.php/djom/article/view/3234

Prastiwi, I. E. (2020). Deposit mudarabah investment risk analysis method value at risk (VAR). International Journal of Economics, Business and Accounting Research (IJEBAR), 4(2), 373-385. https://doi.org/10.29040/ijebar.v4i02.1129

Rachmawati, E., \& Syamsulhakim, E. (2004). Factor affecting mudaraba deposits in Indonesia. Working Paper in Economics and Development Studies. Center for Economics and Development Studies, Department of Economics, Padjadjaran University. Retrieved from http://ceds.fe.unpad.ac.id/publications/wopeds/289-factors-affectingmudaraba-deposits-in-indonesia.html

Rahman, M.H. (2015). Guarantee of investment deposits in Islamic banks: A fiqhi analysis. Journal of Islam, Law and Judiciary, 1(3), 37-53.

Rosly, S. A., \& Zaini M. A. M. (2008). Risk-return analysis of Islamic banks' investment deposits and shareholders' fund. Managerial Finance, 34(10), 695-707. http://dx.doi.org/10.1108/03074350810891010

Seho, M., Alaabed, A., \& Masih, M. (2016). Risk-sharing financing of Islamic banks: Better shielded against interest rate risk?. The Journal of Muamalat and Islamic Finance Research, 13(2), 53-70. Retrieved from https://jmifr.usim.edu.my/index.php/imifr/article/view/29 
Umam, Salam, \& Rizal

Determinants of Mudharabah Term Deposit: ...

Sundararajan, V., \& Errico, L. (2002). Islamic financial institutions and products in the global financial system: Key issues in risk management and challenges ahead. IMF Working Paper No.

WP/02/192, International Monetary Fund. Retrieved from

https://www.imf.org/external/pubs/ft/wp/2002/wp02192.pdf

Sutrisno. (2020). Factors affecting mudaraba deposit in Islamic commercial bank in Indonesia.

Proceedings of the 17th International Symposium on Management (INSYMA 2020). https://doi.org/10.2991/aebmr.k.200127.080

Tyser, C. R., Demetriades, D. G., \& Effendi, I. H. (2000). The Mejelle: A complete code of Islamic civil law. Kuala Lumpur: The Other Press,

Venardos, A. M. (2005). Islamic banking and finance in South-East Asia: Its development and future. World Scientific Books, World Scientific Publishing Co. Pte. Ltd.

https://doi.org/10.1142/5751 